\title{
Equitable and Quality Education for All of Africa? The Challenges of Using ICT in Education
}

\author{
Shanil Samarakoon \\ University of New South Wales, Sydney \\ s.samarakoon@unsw.edu.au \\ Amé Christiansen \\ Melbourne Graduate School of Education, University of Melbourne \\ amechristiansen@gmail.com \\ Paul G. Munro \\ School of Humanities and Languages, University of New South Wales \\ paul.munro@unsw.edu.au
}

\begin{abstract}
Technological advances are increasing interest in the potential role of information and communication technologies (ICT) in enabling quality education outcomes in Africa. At present, however, the geographies of ICT use in Africa is poorly understood, and ICT education policy development has occurred in a relative empirical void. Relevant studies have largely been focused on wealthier African nations, largely neglecting poorer regions where education issues are most acute. This article works to address this lacuna. Drawing upon extensive fieldwork, it provides a detailed snapshot of ICT use in education in the northern Sierra Leonean district of Koinadugu. We subsequently argue that a lack of access to electricity, along with limited numbers of qualified teaching staff, presents fundamental barriers for realizing ICT use in classroom settings. Nevertheless, we also identify some promising trends with respect to the informal use of mobile Internet by teachers and students to augment learning in the classroom.
\end{abstract}

\section{Keywords}

Africa - education - information and communication technologies - mobile phones Sierra Leone - sustainable development goals 
As a part of its 2030 development agenda, on September 23, 2015 the United Nations (UN) passed Sustainable Development Goal 4 (SDG4) "[to] ensure inclusive and equitable quality education and promote lifelong learning opportunities for all" (UNDP 2015). It is a goal that has particular pertinence for sub-Saharan Africa, where it is estimated that half of the approximately 57 million children that remain out of school are located (UN 2016). The declaration of SDG4 marks a significant evolution from the preceding 'education goal' in the Millennium Development Goals, which had a more restricted focus on realizing universal primary education (Haggard 2015). In many ways, SDG4 has built the transformative impact of education rhetoric that formed the basis of the Second Decade of Education for Africa (2006-2015) Plan of Action, which noted that:

Education forms the basis for developing innovation, science and technology, in order to harness our resources, industrialise, and participate in the global knowledge economy and for Africa to take its rightful place in the global community. It is also the means by which Africa will entrench a culture of peace, gender equality and positive African values.

WORLD BANK 2012:3

Within this conversation of improving global education outcomes, information and communications technologies (ICT)-devices such as cellular phones, tablets, computers, and their related applications and softwarehave long been cited as a key resource to better prepare young people to participate in a global knowledge economy. In particular, Internet access (either through computers or mobile phones) has been widely recognized as having great opportunities to expand student learning, not just in terms of access to curriculum-relevant information, but also in transforming student agency, and strengthening their voices as they explore their place in the world (Porter et al. 2016). Nevertheless, despite the development of aspirational nationallevel government policies, ICT use in education is still at an embryonic stage in most sub-Saharan Africa nations (UNESCO 2015; World Bank 2012). Notably, this research also suggests that significant success with respect to ICT access and utilisation in sub-Saharan Africa has largely been restricted to wealthier nations such as South Africa, Botswana, Mauritius, and Seychelles (UnESCO 2015). In particular, there is a dearth of empirical research on ICT access and use in education across low resource, war-affected nations across the continent. 
This suggests that 'digital poverty' does not only exist in terms of access to ICTs (Adera et al. 2014), but also in terms of our knowledge of how ICTs are currently being utilized in poorer nations and/or regions. This is a critical problem as the United Nations (2016) estimates that 50 percent of children who do not access school live in post-conflict countries.

In this article, we work to help address this empirical gap by exploring the contours of ICT use in education in the low-resource, post-conflict context of Sierra Leone, classified by the UN as one of the least-development nations in the world (UNDP 2015). Specifically, we examine the use of ICT across primary and secondary schools in the Koinadugu District, geographically Sierra Leone's largest yet poorest district (World Bank 2010). Our discussion is focused on the relationship between energy use and education, ICT use by students, as well as ICT competency and usage among teachers.

In 2015, the UNESCO Institute for Statistics (UIS) published a comparative analysis of e-readiness in sub-Saharan Africa that outlined the state of ICT use across the continent. 'E-readiness' in this context is defined as the degree to which a country can partake in online digital activities and thus use ICT in education (Dada 2006, cited in UNESCO 2015:6). Seychelles, Mauritius, South Africa, Botswana, and Namibia are the highest performing sub-Saharan African nations in terms of the proportion of pupils in primary school with radio, television, and computer access, with each nation having a minimum of 60 percent across all three technologies (UNESCO 2015:7). However, the study also acknowledges the perennial issue of there being a lack of systematic data collection to measure the impact of ICT in education across many sub-Saharan Africa nations (UNESCO 2015). For instance, there is a glaring absence of data on Nigeria, the most populous nation and the second largest economy after South Africa (ввС 2016). As such the UIs has identified the collection of more and better quality statistics as a priority in the post-2015 development agenda (UNESCO 2015). This is especially pertinent as ICT is expected to play an increasing role in achieving the SDG4 objective of universal 'Quality Education' (UNDP 2015). This perspective is further supported by the World Bank's report on ICTs for Education in Africa, which identified a "lack of accurate, comprehensive, up-to-date data on education" as a challenge across the continent (World Bank 2012:15). Among the report's many recommendations was the need for nations to upgrade educational management information systems (EMIS) in order to better capture and share knowledge while strengthening 
national and regional capacity to identify both challenges and opportunities (World Bank 2012).

A basis for these e-readiness programs is a popular belief in the ability of ICT to empower teachers and learners by fostering the development of twentyfirst century skills. Yet the data and evidence to support these benefits remains elusive (Porter et al. 2016; World Bank 2012). Though many African nations are investing in ICT to improve quality and increase access to education, increased expenditure is not necessarily translating into the expected improvements to educational outcomes (Piper et al. 2015; Porter et al. 2016; World Bank 2012). Literature on ICT and its impact on educational outcomes is replete with inconsistencies and contradictions that make simple cause-effect statements problematic (UNESCO 2015). As such it would appear that the benefits and impacts that can be reliably measured are more functions of how well ICT is deployed rather than the specific nature and quantity of the technologies that are used (Porter et al. 2016; World Bank 2012). This discrete focus on deployment is problematic, as May et al. (2014) note, ICTs can best be defined as a process, rather than simply as products. Their impacts and use are heavily contingent on, and entangled with, a whole range of other policy and program factors (Piper et al. 2015). This can be seen in Sierra Leone. While its Ministry of Information and Communications developed a national ICT policy in 2009 (Jackson 2015), UNESCO (2015) still classes Sierra Leone as being among many African nations that do not appear to have clear planning frameworks and data collection mechanisms in relation to furthering ICT use in education. Thus, while ICTs are broadly celebrated as a key resource for education in Africa, we have a very poor understanding of how they are being utilized and how they are performing.

One of the critical issues undermining ICT use in Africa has been a lack of access to electricity (World Bank 2015). According to UIs data, access to electricity in primary schools in many Africa nations, such as Burkina Faso, the Democratic Republic of Congo, Malawi, and Tanzania, is less than 20 percent (UNESCO 2015:12). Data from Sierra Leone from 2012 on access to electricity in educational institutions indicates that only 3 percent of primary schools and 16 percent of lower secondary schools have access (Ibid). Electricity at the household level is similarly bereft. The International Energy Agency (2014) estimates the "direct connect" rates to electricity in Sierra Leone are only 5 percent (11 percent in urban areas; 1 percent in rural areas). In contrast, Botswana, Djibouti, and South Africa have electricity in 75 percent of primary schools while both Seychelles and Mauritius have 100 percent access in primary schools, the latter being consistent outliers in UIS data (UNESCO 2015:2). Some form of access 
to electricity is a precursor for all ICTs, and therefore the widespread areas of energy poverty across sub-Saharan Africa represent a fundamental barrier to ICT use, not just in education, but for society in general.

Another significant factor that has been recognized as hindering the integration of ICT in education in Africa has been the limited computer literacy of teaching staff in many settings and the challenges this presents for attempts to integrate ICT in education from a pedagogical perspective (World Bank 2012, World Bank 2016). The focus therefore is not just about how to disseminate ICTs, but also poses questions about how best to support teachers to facilitate ICT integrated learning environments (World Bank 2012). Porter et al. (2016), for example, note that while there are many national and regional ICT initiatives such as the New Partnership for Africa's Development, Intel World Ahead, SchoolNET, One Laptop Per Child, and the Pan African Research Agenda, most of these initiatives do not fully integrate ICT with effective instructional programs. There has essentially been an add-ICTs-and-wait approach, rather than an appreciation of how technologies are always situated in social, cultural, and political contexts. There has been a "technological fix" assumption, rather than a focus on understanding the roles that different actors, institutions, and processes play in shaping the use of ICT in education (Munro et al. 2017), and what the implications of these have for ICT policy.

Given the challenges of limited electricity access and poor computer literacy, mobile phone technology platforms are increasingly seen as an appropriate ICT medium to promote education (World Bank 2012). This is not least because of the rapid uptake of mobile phones (including ${ }_{3} \mathrm{G}$-enabled phones and networks) across Africa and other parts of the developing world, effectively leapfrogging not only landline phones, but also computers in terms of the main technology through which the internet is accessed (Collier and Venables 2012; Stork et al. 2013; Piper et al. 2015; Porter et al. 2016). Mobile phones, in part, are able to subvert some of the problems of electricity access as their portability and energy storage capacity (in contrast to desktop computers) allows users to be dynamic in sourcing electricity supply points (Kemeny et al. 2014). Sierra Leone is an exemplar of this mobile phone dynamic. Despite experiencing devastating civil war during the 1990s that resulted in the widespread destruction of the nation's infrastructure, Sierra Leone's mobile phone ownership rates (over $5^{\circ}$ percent) and network coverage (over 80 percent) are widespread (Sam 2015:3). Ownership and use rates are likely to continue to increase, as the influx of cheap web-enabled Chinese phone brands and the relatively low cost of both pre-paid and post-paid data are driving wider adoption (Sam 2015). 
Despite this massive upsurge of mobile phone use, there have been only limited studies conducted on the impact that these new communication technologies have had on education programs and outcomes (Piper et al. 2015; Porter et al. 2016). Most mobile-learning projects are explorative and experimental pilots that do not scale up, perhaps owing to the rapid pace of advancements in technology (UNESCO 2012). In their mixed-method research project across Ghana, Malawi, and South Africa, Porter et al. (2016) observed that mobile phones seemed to play a more "mundane" role in the promotion of education. This often ranged from peer support with homework to information searches on key concepts and checking examination results, suggesting that there is scope for the depth of integration and use to improve. Recent research by Sam $(2015,2017)$ has noted how this rapid uptake of mobile phones can result in all sorts of positive effects, such as allowing for marginalized youth to exercise personal agency and establish a sense of connection, as well as for opportunities to facilitate reunions with family members that had been displaced during civil war. In a similar vein, Sey and Ortoleva (2014) assert that a rigid focus on measuring educational outcomes might lead to valuable and popular uses of mobile phones, such as social networking and gaming (both educational and non-educational), being undervalued as a means to build social capital and digital competency in the developing world (Sey 2011). This is a sentiment that is shared by Mooketsi and Chigona (2014) in their examination of ICT use in disadvantaged schools in Cape Town, South Africa. However, there is also evidence of negative effects including the increasing uptake of online gaming (Sam 2015), and suggestions that mobile phones open and facilitate new avenues for student bullying and sexual harassment (Porter et al. 2016). Porter et al. (2016), Anyanwu (2016), and UnEsco (2012) also identify gender disparities in access to mobile phones that can be attributed to unequal distribution of income, restrictive social and cultural practices, and high illiteracy rates among women. Thus, while mobile phones offer a potentially powerful ICT for education, there is still a need to appreciate the social, cultural, and political contexts in which they are situated (Sam 2017). In light of these complex impacts, there appears to be a need to build both psychological and technical readiness among both teachers and students (Piper et al. 2015). Mobile phone technology, whether planned or not, will become a part of education in Africa in many informal ways, and therefore the challenge for policy makers is to craft positive outcomes from this disruptive technology.

It is therefore clear that in order to support more ICT in education approaches in Africa there is a critical need for more detailed research on the existing dynamics of ICT use from different contexts. At present the ICT use geographies in Africa, and in much of the developing world, are poorly understood 
and therefore ICT education policy development occurs in a relative empirical void. This article is a direct response to this situation, drawing upon data from a poor and relatively marginalized region of sub-Saharan Africa to provide insights into some of the challenges that might lie ahead.

\section{Methodology}

The research in this article is focused on the Koinadugu District of Sierra Leone (see Figure 1), the nation's largest district by geographic area. The district is divided into 11 chiefdoms and its capital city Kabala is one of the largest urban centres in northern Sierra Leone. The research was conducted in 2014. The three main data collection methods used in this project were student surveys, teacher interviews, and secondary data analysis. As illustrated in Figure 2, Sierra Leone's secondary and primary education system is sub-divided into three components: Primary School (six years), Junior Secondary School (three years) and Senior Secondary School (four years). Our study sampled 31 Junior Secondary Schools (JSS) and five Senior Secondary Schools (sss) located across the Koinadugu District (see Appendix, Table 3). A short structured survey was conducted with students in JSS2 and JSS 3 to collect both quantitative and qualitative data; between 20 and 60 surveys were conducted at each school (participation rates varied depending on the size of the school and the availability of students), with 806 students being surveyed in total. The survey questions focused on the students' access to lighting and ICTs, at home and at school, as well as their study habits. A more detailed survey was conducted with $\mathrm{SS}_{3}$ and $\mathrm{SS}_{4}$ students. The surveys included detailed questions about studying habits, lighting use, and ICт access, as well as their aspirational perspectives in terms of what difference the provision of electricity and lighting at the school would mean for their education. Between 20 and 26 students were surveyed at each of the senior secondary schools, with 107 students being surveyed in total.

Short interviews were conducted with 133 Jss teachers and 18 sss teachers. This included teachers from a range of different disciplines (e.g., mathematics, history, science, etc.) as well as vice principals and principals. Some teachers were new to their positions (less than a year's experience); while others had been involved in the profession for many years, including one principal with 39 years of teaching experience. The teacher interviews focused on the teacher's ICT use, technology access that was available at their schools, night-time use of school facilities, changing trends in student attendance, and the potential that lighting and ICTs could have in terms of transforming education. 


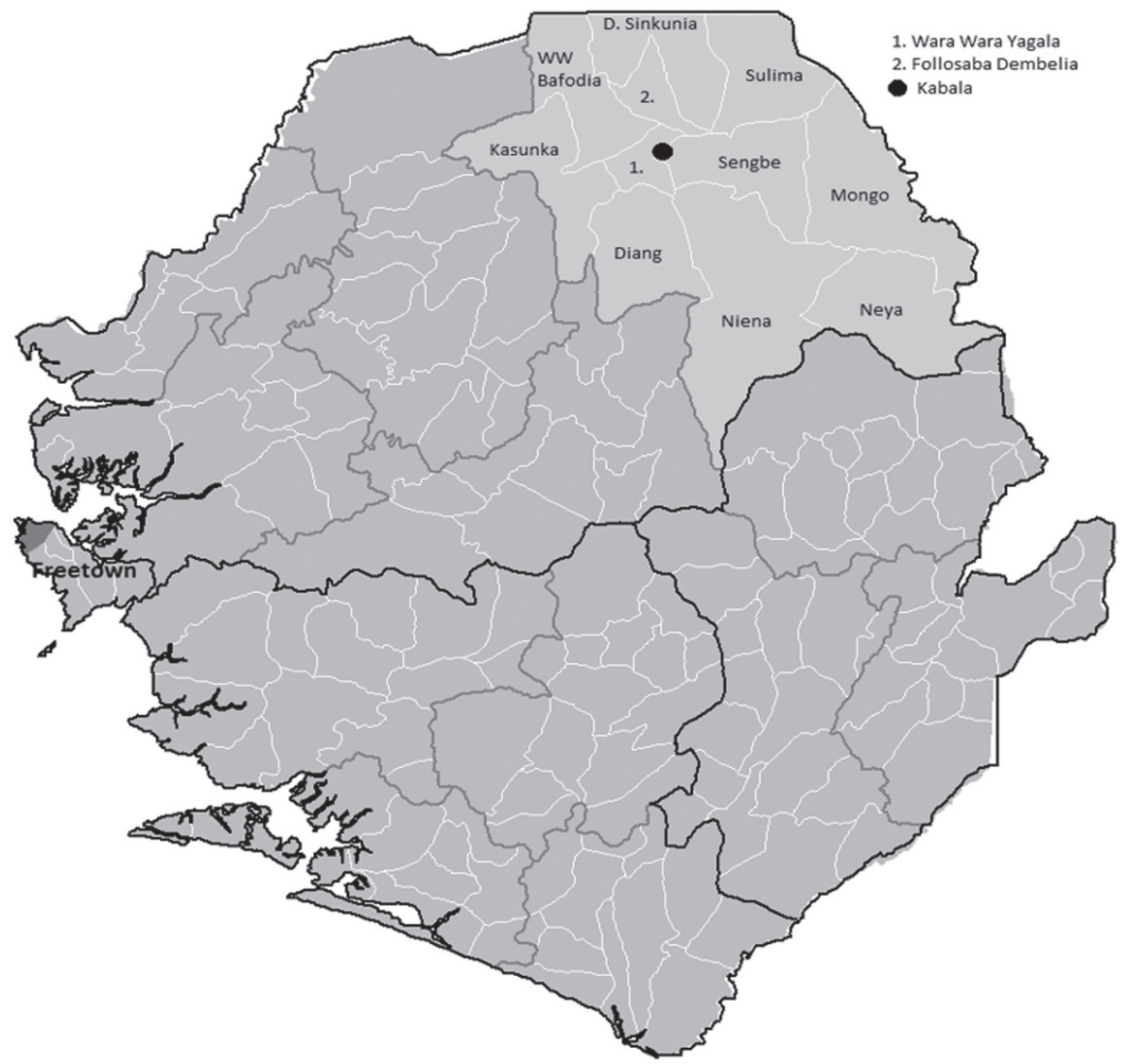

FIGURE 1 Map of Sierra Leone with Koinadugu's Chiefdoms highlighted.

\begin{tabular}{|c|c|c|c|c|c|c|c|c|c|c|c|c|c|}
\hline \multicolumn{6}{|c|}{ Primary School } & \multicolumn{3}{|c|}{$\begin{array}{c}\text { Junior Secondary } \\
\text { School }\end{array}$} & \multicolumn{4}{|c|}{$\begin{array}{c}\text { Senior Secondary } \\
\text { School }\end{array}$} & \multirow{2}{*}{ Tertiary Education } \\
\hline P1 & P2 & P3 & P4 & P5 & P6 & JSS1 & JSS2 & JSS3 & SS1 & SS2 & sS3 & SS4 & \\
\hline
\end{tabular}

FIGURE 2 Structure of the Sierra Leonean education system.

Finally, school data was collected from the 36 schools (Jss and sss) in terms of school enrollment numbers, teacher numbers and qualifications, as well as Basic Education Certificate Examination (BECE) and Western African Senior School Certificate Examination (WASSCE) results. There were some gaps in this data owing to the fact that not all schools had their exam results. 
It is widely acknowledged that access to modern energy is critical for certain forms of development (Bhattacharyya 2012; Sovacool and Drupady 2012), as the former UN General Secretary Ban Ki-Moon (UN 2014) noted, "Sustainable energy is the golden thread that connects economic growth, increased social equity and an environment that allows the world to thrive." In this vein, the ability of Sierra Leone's rural poor to transcend poverty, not unlike communities in similar rural contexts, is hinged upon access to reliable and affordable energy access. Nevertheless, in its post-war context, Sierra Leone's electricity supply has remained a constant and economically pernicious problem (Munro et al. 2016). For example, in 2014, the International Energy Agency (IEA 2014) estimated that only five percent of the population had direct access to electricity; in rural areas access was estimated to be only one percent. The clear majority of electricity connections are limited to the major urban centres, such as the capital city Freetown and district capitals, leaving the rest of the country with little or no grid access (Willans et al. 2011). In response to this problem, many households and businesses use small gasoline or diesel-powered generators as their main source of electricity (Munro et al. 2016). This option remains far beyond the reach of most citizens however, and among the (majority) rural population, generator ownership is only around one percent (MEWR 2009). On the whole, as Munro et al. (2016: pg. 29) note, "although infrastructure reconstruction has been vigorously pursued, the situation seems little likely to change for rural communities in the near term. Due to the severe national energy deficit, electrification projects have necessarily been focused on supplying the concentrated demand of urban centres and plans for improved rural electrification remain largely aspirational". In this context, it is therefore unsurprising that Koinadugu District's relatively isolated rural population is experiencing a form of energy poverty that has direct implications for ICT use and education outcomes more generally.

\subsection{Lighting}

This lack of electricity does not only have implications for access to relatively "high tech" ICTs such as computers and Internet-enabled mobile phones, but also for the more prosaic issue of trying to access basic lighting. This has direct implications for educational outcomes, as it is common for students across sub-Saharan Africa to build upon the lessons of the day by studying at night, often congregating under whatever light source is available to them (Gustavsson 2007). This holds true in Koinadugu where night-time was the 
preferred time of study for both Jss ( 96 percent) and sss (69 percent) students. However, their ability to study at night is often constrained by poor lighting options and cost barriers. In fact, cost was cited as a major issue for the majority of students (93 percent Jss, 94 percent sss).

Among Jss students, the most common source of household lighting for study were battery powered torches (47.8 percent), followed by candles (40.8 percent), with Solar Home Systems (sHSs), kerosene lamps, and generators forming the rest of the mix (between one percent and four percent each); 4.4 percent of students reported that they had no lighting source at home (see Table 1). For sss students, the variation was slightly different, with the majority reportedly using candles (65 percent) for household lighting, with batterypowered torches being the second most popular (21 percent). There was, however, substantial variation on a school-by-school basis. Some remote, junior secondary schools had more than three quarters of their students using candles for lighting, (i.e., Kondeiah, Yiraia, UMC Heritage, and Mongo Agricultural), while in Kabala a high proportion of students had access to generators for lighting (24 percent), and a further ten percent reported that they had small SHSs. The relative high number of sHS users is undoubtedly a result of sales from energy kiosks that NGO Energy For Opportunity (EFO) set up in Kabala Town in 2013 and 2014 (Munro et al. 2014).

It should be noted that the cost of lighting does not just present an issue of an absolute barrier to lighting, but it also dictates the quality of lighting that is made available to young people for education. The patriarchal and gerontocratic organisation of parts of Sierra Leonean society (particularly in rural areas) (Hoffman 2003), can result in household contexts where the lighting needs of adults takes precedence over those of children, resulting in the latter using less-suitable forms of lighting, like candles. This is a concern, as lighting from candles (as well as kerosene) is widely acknowledged as providing an insufficient quality of light for reading (Munro et al. 2016; Pode 2010).

Given the lack of adequate lighting across many households in Koinadugu, it is unsurprising that students expressed a preference to study at their school at night. It also presents an opportunity for them to interact with their peers and teachers and whatever printed resources the schools may available. However, this too is constrained by the lack of access to improved sources of lighting across the majority of schools in the district. Unsurprisingly, the quality of lighting available at school is closely linked to how students perceive its safety at night. With the exception of the aforementioned example of Loma (ten percent), more than half of the sss students reported that they felt their school was unsafe at night. These Secondary Schools often struggle to cover the running costs of generators (e.g. St. Anthony and Kabala Secondary School) and typically required students to bring their own lighting sources. It is therefore 
TABLE 1 Variation in Students' household lighting use across three Jss/sss schools in the Koinadugu District

\begin{tabular}{lccccc}
\hline & AMASS & Bafodia & Kabala & Loma & Mongo \\
\hline Kerosene & $0 \%$ & $15 \%$ & $0 \%$ & $3 \%$ & $0 \%$ \\
Candles & $72 \%$ & $47 \%$ & $31 \%$ & $58 \%$ & $81 \%$ \\
\hline Torch & $26 \%$ & $27 \%$ & $36 \%$ & $33 \%$ & $19 \%$ \\
LED Lamps & $0 \%$ & $0 \%$ & $0 \%$ & $0 \%$ & $0 \%$ \\
SHS & $0 \%$ & $0 \%$ & $10 \%$ & $3 \%$ & $0 \%$ \\
Nothing & $0 \%$ & $0 \%$ & $0 \%$ & $0 \%$ & $0 \%$ \\
Other & $2 \%$ & $12 \%$ & $0 \%$ & $3 \%$ & $0 \%$ \\
Generator & $0 \%$ & $0 \%$ & $24 \%$ & $3 \%$ & $0 \%$ \\
\hline
\end{tabular}

evident that access to quality lighting appears to present a major barrier for students in Koinadugu District. Moreover, given that access to electricity is a precursor to the use of ICT, the pervasive energy poverty across the district would appear to foreshadow the extent to which it is used for educational purposes. The necessity of energy access in such contexts would also suggest that ICT policy cannot be separated from energy policy.

\subsection{ICTs and Students}

Schools across Sierra Leone have poor access to ICT infrastructure and Internet access. In the case of Koinadugu, only a minority of students had experience using computers: three percent of Jss and 11 percent of sss students. The students who had used computers were almost exclusively from schools located in Kabala (i.e., UMC Heritage, Loma, Kabala, AMAss), suggesting an urbanrural divide. Even still, computer use was a very occasional activity, usually at Internet cafes in the urban centres of Kabala or Makeni. Not a single student surveyed reported using a computer regularly (i.e., on a weekly basis). Out of all of the Jss and sss schools surveyed, only Dankawali reported actually owning computers; the school, however, had no form of electricity access and therefore the (potential) use of them in classes was impossible.

The lack of computers at schools and households across the Koinadugu District is perhaps unsurprising given the general lack of electricity within schools and households. The current "energy poverty" situation of the District has essentially rendered the use of computers in schools virtually impossible. This is unfortunate as the small minority of sss students who did report having used computers and accessing the Internet stated that they had used it for 
educational purposes (studying: 49 percent; reading: 32 percent). The entire cohort of sss students surveyed, along with the teachers interviewed, all stated that they believed computers represented a very important education tool that should be integrated into school programs.

Access to mobile phones, however, was considerably stronger and in conjunction with improving $3 \mathrm{G}$ coverage across Sierra Leone, there is some evidence that they were being used for educational purposes. There was a reasonable degree of access to mobile phones among the students' households. Across the Jss students, 43 percent of those surveyed reported that their household owned a mobile phone. There was, however, great variation between the schools with all students from some villages reporting no mobile phone ownership (i.e., Gberefeh Alhakra, Siradu, Yiraia, Bambukoro), while others, mainly those located in Chiefdom Headquarter Towns and Kabala, reported high levels of ownership (i.e., over go percent). Only a small minority (two percent) of the Jss student households' mobile phones were smartphones that could access the Internet through a $3 \mathrm{G}$ network. Household mobile phone ownership was higher among sss students (64 percent), as was access to $3 \mathrm{G}$ internet via their phones (35 percent). Mobile phone ownership and $3 \mathrm{G}$ access, however, was dominated by students from the ssss in Kabala (i.e., Loma, Kabala, and AMASs). Students with $3 \mathrm{G}$ internet access in Kabala frequently used their phones as a studying aid (see Table 2). Thus, informally at least, students with access to these technologies are often using them to further their education.

TABLE 2 Overview of Mobile Phone ownership and use across the five ssss in Koinadugu District: AMASs, Kabala and Loma are all located in Kabala, the District Capital

\begin{tabular}{|c|c|c|c|c|c|c|}
\hline & & AMASS & Bafodia & Kabala & Loma & Mongo \\
\hline \multicolumn{2}{|c|}{ Household mobile ownership } & $100 \%$ & $15 \%$ & $100 \%$ & $100 \%$ & $19 \%$ \\
\hline \multicolumn{2}{|c|}{ Internet $\left({ }_{3} G\right)$ on mobile phone } & $35 \%$ & $10 \%$ & $67 \%$ & $65 \%$ & $4 \%$ \\
\hline \multirow{4}{*}{$\begin{array}{l}\text { Frequency } \\
\text { phone } \\
\text { internet use }\end{array}$} & Regular & $10 \%$ & $0 \%$ & $29 \%$ & $30 \%$ & $0 \%$ \\
\hline & Occasional & $15 \%$ & o\% & $38 \%$ & $25 \%$ & $4 \%$ \\
\hline & Rare & $10 \%$ & $0 \%$ & $0 \%$ & $5 \%$ & $4 \%$ \\
\hline & Never & $65 \%$ & $100 \%$ & $33 \%$ & $40 \%$ & $92 \%$ \\
\hline \multicolumn{2}{|l|}{ Phone used for study } & $35 \%$ & $0 \%$ & $52 \%$ & $45 \%$ & $4 \%$ \\
\hline \multirow[t]{3}{*}{ Study use } & Reading & $57 \%$ & & $30 \%$ & $10 \%$ & $100 \%$ \\
\hline & $\begin{array}{l}\text { Search } \\
\text { information }\end{array}$ & $43 \%$ & & $70 \%$ & $80 \%$ & $0 \%$ \\
\hline & Other & o & & $0 \%$ & $10 \%$ & $0 \%$ \\
\hline
\end{tabular}


Overall, while there is a relatively high level of Internet access through mobile phones in Koinadugu District, especially when compared to computers, this use is almost exclusively concentrated in Kabala, the District's capital, indicating that there is a considerable urban-rural divide. This divide extends to gender, particularly across high schools in the District. Girls in Sierra Leone face several barriers to realizing their education; this reportedly includes high rates of early marriage, teenage pregnancy, extra fees, and lack of proper parental guidance, as well as sexual exploitation in schools (Botti 2010; Brock and Cammish 1997; UNICEF 2012), the latter is of particular concern given the high ratio of male-to-female teachers. Our study, consistent with findings from UNICEF (2012) found that there was a dramatic drop in female student participation after the first couple of years of junior secondary school. In light of the broader trends towards mobile phone ownership and use of mobile Internet in Sierra Leone and Koinadugu District, the use of such ICт by girls of schoolgoing age, particularly in rural contexts, could be a valuable avenue for study. Particularly as access to ICT could improve access to valuable information, a range of social perspectives and educational opportunities that could in turn contribute positively to gender equality (Anyanwu 2016).

\subsection{ICTs and Teachers}

The school demographic data, from the 25 schools from which it was available, paints a picture of concern in terms of teacher qualifications and geographies. Only 11 percent of teachers held a university qualification, while 60 percent held a teaching certificate; nearly one third (29 percent) had no teaching qualifications at all. An earlier report by Wang et al. (2007) produced similar findings, noting that the northern region of Sierra Leone (in which Koinadugu District is located) has the highest proportion of unqualified teachers in Sierra Leone. Overall, only 45 percent of these teachers were salaried workers, the majority ( 55 percent) work as "volunteer" teachers, presumably receiving direct payments from families for teaching services rendered. This is a common scenario in Sierra Leone, with a 2007 survey indicating that 50.4 percent of school teachers in Sierra Leone had secondary jobs to meet their financial needs (Nishimuko 2007). This high level of underqualified and unqualified teachers is a critical challenge when considering the development of ICT pedagogy in schools, as it likely indicates there is a severe lack of capacity to provide teaching expertise in general, let alone in the development of educational programs that integrate ICTs. This connection is highlighted by May et al. (2014) who note that ICTs can best be defined as a process-the impact of ICTs and their use are heavily entangled with a whole range of other policy and program factors. Formal integration of ICTs into Koindadugu's 
education program will likely always pose a challenge, given the fundamental lack of qualified education staff.

Nevertheless, while the formal integration of ICTs in education appears to be problematic, the research reported here indicates that informally at least, many teachers had been drawing upon these technologies to aid their teaching. Across the sss teachers interviewed, 68 percent owned mobile phones and 53 percent had Internet access (via a $3 \mathrm{G}$ network) on their phone. Like the students, there was a distinct geography to this ownership and access. All of the sss teachers based in Kabala owned mobile phones with ${ }_{3} \mathrm{G}$ Internet access; in Mongo, while four out of the five teachers owned a mobile, only one had ${ }_{3} \mathrm{G}$ Internet access while no teacher based at Bafodia sss owned a mobile phone. Those teachers with ${ }_{3} \mathrm{G}$ access noted that they accessed the Internet regularly, and often used it to aid in their teaching in terms of reading and searching for information. Thus their phones informally operated as a pedagogical tool in their teaching.

With SDG4, the UN has committed to ensure that by 2030, "All girls and boys [are able to] complete free, equitable and quality primary and secondary education leading to relevant and effective learning outcomes" (UNDP 2015). ICTS are widely viewed as a critical part of this education future (UNESCO 2015; World Bank 2012). The current situation of ICTs and education in Koinadugu provides critical insights into some of the challenges and opportunities that ICTs might offer for poor and remote areas of sub-Saharan Africa.

Given that electricity is an essential prerequisite for ICTs, the low levels of electrification across Koinadugu District present a fundamental barrier to ICT access and use in education. And, given that more than 620 million people do not have direct access to electricity in the sub Saharan African region (IEA 2014), Koinadugu may serve as an example of how critical energy access is, not just to ICT access and use, but to education and development more generally. In this regard, data from Koinadugu suggests that off-grid solar systems, especially in school buildings, could play an important role in addressing energy poverty in rural regions that are unlikely to gain access to the grid in the foreseeable future. Our observations support the assertion that energy and ICT policies need to be co-developed and co-implemented if the espoused potential of ICT in education is to be realized, particularly in rural regions.

Similarly, the lack of teacher capacity to integrate ICTs into teaching practice in Koinadugu is likely to reflect a broader challenge across the sub-Saharan 
Africa region (Piper et al. 2015; Porter et al. 2016; UNESCO 2015, World Bank 2012). This challenge is particularly acute in Koinadugu as nearly one third of teachers in the region possessed no teaching qualifications and over half were volunteers. This raises questions with respect to the general teaching capability and capacity within these predominantly rural schools, let alone matters of technical competency. Unsurprisingly, the ground realities observed in schools in Koinadugu would suggest that the effective use of ICTs is contingent on the efficacy of systematic national efforts to build teaching capacity through training programmes (Porter et al. 2016). Furthermore, the effective use of ICT in education requires more than an emphasis on technical competency with a range of hardware and software (Piper et al. 2015), it requires the integration of ICTs into everyday pedagogy. As such, there is a need for ICT use to be embedded into curricula in order to promote more active and contextually relevant use of technology in subject preparation and delivery (Muianga et al. 2013), as opposed to reliance on assessing ICT as an add on subject (Piper et al. 2015).

With respect to opportunities, it is encouraging to note that both students and teachers in Koinadugu are already using ${ }_{3} G$ Internet for educational purposes, albeit informally. While concentrated in urban centres like Kabala, this is a promising trend as the diminishing costs of mobile phones and $3 \mathrm{G}$ Internet (Sam 2015) could allow for more convenient and affordable ICT access at both a school and household level. It would appear that smartphones may be better poised to overcome the urban-rural digital divide as compared to more capital, energy, and labor-intensive (maintenance) technologies such as computers (Piper et al. 2015; Porter et al. 2016). Asiedu (2012) makes both a compelling and pragmatic argument in favor of leveraging the ubiquity of radios in African households in order to promote "high tech" ICT options, particularly in rural and marginalized regions. This could range from general information on affordable technology options such as smartphones, to more specific discussions on useful websites, applications, and responsible practices (Porter et al. 2016). Given the lack of access to electricity and computers in Koinadugu, the use of radio as a medium could complement the effective use of ICT; and indeed radio is the main medium that Sierra Leone's rural populace accesses for news beyond their local context (Fortune et al. 2011). However, given the complex social barriers and implications of mobile phone ownership and use, policy makers in nations like Sierra Leone need to be conscious of gender and geographic disparities (UNESCO 2015 and factor the responsible use of technology into national training initiatives (Porter et al. 2016). Furthermore, as Nchunge, Sakwa, and Mwangi (2012) argue, more successful ICT adoption requires that teacher training programs focus on developing both technical and psychological readiness. The latter, which is often overlooked, refers to the fundamental 
beliefs, attitudes, and intentions that shape the likelihood of teachers accepting and incorporating ICT into their practice.

Finally, the empirical evidence in this study exemplifies the need for more systematic data collection across schools in the sub-Saharan Africa region, a recommendation that is echoed in recent UNESCO (2015) and World Bank (2012) reports on ICT in education. In the case of Sierra Leone, consistent data collection from schools could facilitate evidence-based ICT policy development (Piper et al. 2015) and in turn drive much needed investment into building local infrastructure and capacity. This is a particularly important consideration in low-resource contexts given that the financial cost of failed ICT investments can be very high (Piper et al. 2015). These efforts could help address the gulf between rhetoric about the great potential of ICT in education and the ground realities of facilitating access and use in low-resource contexts across sub-Saharan Africa.

\section{References}

Adera, Edith Ofwona, Timothy M. Waema, Julian May, Ophelia Mascarenhas, and Kathleen Diga (Eds.) 2014. ICT Pathways to Poverty Reduction: Empirical Evidence from East and Southern Africa. Rugby: Practical Action Publishing.

Anyanwu, John C. 2016. "Accounting for Gender Equality in Secondary School Enrollment in Africa." African Development Review 28(2):170-191.

Asiedu, Christobel. 2012. "Information communication technologies for gender and development in Africa. The case for radio and technological blending." International Communication Gazette 74(3):240-257.

ввC. 2016. "South Africa regains 'Africa's biggest economy' title from Nigeria." BBC.com (http://www.bbc.co.uk/news/world-africa-37045276).

Bhattacharyya, Subhes C. 2012. "Energy access programmes and sustainable development: A critical review and analysis." Energy for Sustainable Development 16(3):260-271.

Botti, Danielle. 2010. "Girls' Education Week: Advocating for equity in Sierra Leone." UNICEF. (https://www.unicef.org/education/sierraleone_56691.html).

Brock, Colin and Nadine Cammish. 1997. Factors affecting female participation in education in seven developing countries (2nd ed.). London: Department for International Development.

Collier, Paul and Anthony J. Venables. 2012. "Greening Africa? Technologies, endowments and the latecomer effect." Energy Economics 34(Supplement 1):75-84.

Fortune, France, Cindy Chungong, and Andrew Kessinger. 2011. "Community Radio, Gender, Iстs in Africa." Search for Common Ground. (https://www.sfcg.org/ programmes/rfpa/pdf/2012-Community-Radio-Gender-ICT_SFCG.pdf). 
Gustavsson, Mathias. 2007. "Educational benefits from solar technology—access to solar electric services and changes in children's study routines, experiences from Eastern Province Zambia." Energy Policy 35(2):1292-1299.

Haggard, E. 2015. "African Education 2.o." African Business 49(421):70-71.

Hoffman, Danny. 2003. "Like beasts in the bush: synonyms of childhood and youth in Sierra Leone." Postcolonial Studies 6(3):295-308.

International Energy Agency (IEA). 2014. Africa Energy Outlook: A Focus on Energy Prospects in Sub-Saharan Africa. (https://www.iea.org/publications/freepublications/publication/WEO2014_AfricaEnergyOutlook.pdf).

Jackson, Emerson A. 2015. "Role of Information Science in Sustainable Development: Sierra Leone as a Case Study." Management of Sustainable Development 7(2):23-29.

Kemeny, Preston, Paul G. Munro, Nicole Schiavone, Greg van der Horst, and Simon Willans. 2014. "Community Charging Stations in Rural Sub-Saharan Africa: Commercial Success, Positive Externalities, and Growing Supply Chains." Energy for Sustainable Development 23:228-236.

May, Julian, Timothy M. Waema, and Elise Bjåstad. 2014. "The ICT/Poverty Nexus in Africa." Pp. 1-32 in ICT Pathways to Poverty Reduction: Empirical Evidence from East and Southern Africa. Edited by Edith Ofwona Adera, Timothy M. Waema, Julian May, Ophelia Mascarenhas, and Kathleen Diga. Rugby: Practical Action Publishing.

Ministry of Energy and Water Resources (MEWR). 2009. National Energy Policy and Strategic Plan-Energy for Poverty Alleviation and Socio-Economic Development, Part I: National Energy Policy. Freetown: Ministry of Energy and Water Resources. Government of Sierra Leone.

Mooketsi, Bojelo E. and Wallace Chigona. 2014. "Different shades of success: educator perception of government strategy on e-education in South Africa." The Electronic Journal of Information Systems in Developing Countries 64(8):1-15.

Muianga, Xavier, Henrik Hansson, Anders Nilsson, Avelino Mondlane, Inocente Mutimucuio, and Alsone Guambe. 2013. "ICT in education in Africa-myth or reality: A case study of Mozambican higher education institutions." The African Journal of Information Systems 5(3):106-117.

Munro, Paul, Greg van der Horst, and Stephen Healy. 2017. "Energy Justice for All?" Energy Policy 105:635-641.

Munro, Paul, Greg van der Horst, Simon Willans, Preston Kemeny, Ame Christiansen, and Nicole Schiavone. 2016. "Social enterprise development and renewable energy dissemination in Africa: The experience of the community charging station model in Sierra Leone." Progress in Development Studies 16(1):24-38.

Nchunge, David Mbabu, Maurice Sakwa, and Waweru Mwangi. 2012. "User's perception on ICT adoption for education support in schools: A survey of secondary school teachers in Thika District, Kenya." International Journal of Humanities and Social Science 2(13):17-29. 
Nishimuko, Mikako. 2007. "Problems behind Education for All (EFA): The case of Sierra Leone." Educate 7(2):19-29.

Piper, Benjamin, Evelyn Jepkemei, Dunston Kwayumba, and Kennedy Kibukho. 2015. "Kenya's ICT Policy in Practice: The Effectiveness of Tablets and E-Readers in Improving Student Outcomes." Information and Communication Technology for Development 2(1):3-18.

Pode, Ramchandra. 2010. "Solution to enhance the acceptability of solar-powered LED lighting technology." Renewable and Sustainable Energy Reviews 14(3):1096-1103.

Porter, Gina, Kate Hampshire, James Milner, Alister Munthali, Elsbeth Robson, Ariane de Lannoy, Andisiwe Bango, Nwabisa Gunguluza, Mac Mashiri, Augustine Tanle, and Albert Abane. 2016. "Mobile Phones and Education in Sub-Saharan Africa: From Youth Practice to Public Policy." Journal of International Development 28(1):22-39.

Sam, Steven. 2015. "Exploring Mobile Phone Use among Marginalised Young People in Post-Conflict Sierra Leone." The Electronic Journal of Information Systems in Developing Countries 66(5):1-20.

Sam, Steven. 2017. "Towards an empowerment framework for evaluating mobile phone use and impact in developing countries." Telematics and Informatics 34:359-369.

Sey, Araba. 2011. "We use it different, different': Making sense of trends in mobile phone use in Ghana." New Media \& Society 13(3):375-390.

Sey, Araba and Peppino Ortoleva. 2014. "All work and no play? Judging the uses of mobile phones in developing countries." Information Technologies and International Development 10(3):10-17.

Sovacool, Benjamin and Ira Martina Drupady. 2012. Energy Access, Poverty and Development: The Governance of Small-scale Renewable Energy in Developing Asia. London: Routledge.

Stork, Christoph, Enrico Calandro, and Alison Gillwald. 2013. "Internet going mobile: internet access and use in 11 African countries." info 15(5):34-51.

United Nations (UN). 2014. "Sustainable Energy 'Golden Thread' Connecting Economic Growth, Increased Social Equity, Secretary-General Tells Ministerial Meeting." Retrieved October 20, 2016. (http://www.un.org/press/en/2014/sgsm15839.doc.htm). United Nations (UN). 2016. "Goal 4: Ensure inclusive and quality education for all and promote lifelong learning." Retrieved November 12, 2016. (http://www.un.org/ sustainabledevelopment/education/).

United Nations Development Programme (UNDP). 2015. Human Development Report 2015: Work for Human Development. New York: United Nations Development Programme.

United Nations Educational, Scientific, and Cultural Organization (UNESCO). 2012. Turning on Mobile Learning in Africa and the Middle East: Illustrative Initiatives and Policy Implications. Retrieved on November 17, 2016. (http://unesdoc.unesco.org/ images/o021/002163/216359E.pdf). 
Unesco Institute of Statistics. 2015. Information and Communication Technology (ICT) in Sub-Saharan Africa: A comparative analysis of basic e-readiness in schools. Retrieved November 14, 2016. (http://www.uis.unesco.org/Communication/Docu ments/ICT-africa.pdf).

UNICE F. (2012). Annual Report 2012 for Sierra Leone: UNICEF. Retrived November 12 th 2016.(https://www.unicef.org/about/annualreport/files/Sierra_Leone_COAR_2012 .pdf).

Wang, Lianqin, Ramahatra Rakotomalala, Laura Gregory, and Paul Cichello. 2007. Education in Sierra Leone: present challenges, future opportunities. Africa Human Development Series, Africa education country status report. Washington, DC: World Bank. (http://documents.worldbank.org/curated/en/618111468166474170/ Education-in-Sierra-Leone-present-challenges-future-opportunities).

Willans, Simon, Amé Christiansen, and Paul Munro. 2011. "Emerging Forms of Entrepreneurship: For-Profit and Non-Profit Partnerships for the Dissemination of Solar Power into Rural Sub-Saharan Africa." Iсsв World Conference Proceedings. International Council for Small business (ICSB).

World Bank. 2010. Empowering Farmers in Sierra Leone's Koinadugu District. Retrieved November 18, 2016. (http://www.worldbank.org/en/news/feature/2010/10/20/em powering-farmers-in-sierra-leones-koinadugu-district).

World Bank. 2012. ICTs for Education in Africa. Retrieved on November 16, 2016. (http://siteresources.worldbank.org/EXTINFORMATIONANDCOMMUNICATION ANDTECHNOLOGIES/Resources/282822-1346223280837/Education.pdf).

World Bank. 2016. ICт Competitiveness in Africa. Retrieved on November 12th 2016. (http://siteresources.worldbank.org/EXTINFORMATIONANDCOMMUNICATION ANDTECHNOLOGIES/Resources/282822-1346223280837/ICTCompetitiveness .pdf).

\section{Appendix}

TABLE 3 Schools Targeted for this Research Project. Jss = Junior Secondary School; sss = Senior Secondary School; ss = number of Student Surveys conducted; $T I=$ number of Teacher Interviews conducted

\begin{tabular}{lllllll}
\hline$\#$ & Schools & Chiefdom & JSs & SSs & Ss & TI \\
\hline 1 & $\begin{array}{l}\text { Movement of Faith (MOF) } \\
\text { Secondary School_Gbentu }\end{array}$ & Follosaba Dembelia & yes & no & 21 & 2 \\
2 & $\begin{array}{l}\text { Government Secondary } \\
\text { School Sinkunia }\end{array}$ & Dembellia Sinkunia & yes & no & 45 & 5
\end{tabular}


TABLE 3 Schools Targeted for this Research Project (cont.)

\begin{tabular}{|c|c|c|c|c|c|c|}
\hline$\#$ & Schools & Chiefdom & Jss & sss & ss & TI \\
\hline 3 & $\begin{array}{l}\text { Kondehbiah Secondary } \\
\text { School }\end{array}$ & Diang & yes & no & 21 & 5 \\
\hline 4 & $\begin{array}{l}\text { Lengekoro Agricultural } \\
\text { Muslim Secondary School }\end{array}$ & Diang & yes & no & 21 & 2 \\
\hline 5 & $\begin{array}{l}\text { Musaia Commercial } \\
\text { Secondary School }\end{array}$ & Follosaba Dembelia & yes & no & 24 & 5 \\
\hline 6 & $\begin{array}{l}\text { Alhakra Agricultural } \\
\text { Secondary School }\end{array}$ & Sulima & yes & no & 60 & 5 \\
\hline 7 & $\begin{array}{l}\text { Government Secondary } \\
\text { School_Falaba }\end{array}$ & Sulima & yes & no & 45 & 4 \\
\hline 8 & $\begin{array}{l}\text { Mongo Agricultural } \\
\text { Secondary School }\end{array}$ & Mongo & yes & yes & 76 & 9 \\
\hline 9 & $\begin{array}{l}\text { Kamaron Community } \\
\text { Secondary School }\end{array}$ & Mongo & yes & no & 30 & 5 \\
\hline 10 & $\begin{array}{l}\text { Gberefeh Comprehensive } \\
\text { Academy Secondary School }\end{array}$ & Mongo & yes & no & 45 & 5 \\
\hline 11 & Loma Secondary School & Sengbe & yes & yes & 40 & 10 \\
\hline 12 & $\begin{array}{l}\text { Ahmadiyya Muslim } \\
\text { Agricultural Secondary } \\
\text { School (AMASs) }\end{array}$ & Sengbe & yes & yes & 41 & 6 \\
\hline 13 & $\begin{array}{l}\text { Bambukoro Agricultural } \\
\text { Secondary School }\end{array}$ & Sengbe & yes & no & 21 & 4 \\
\hline 14 & $\begin{array}{l}\text { Dankawallie Secondary } \\
\text { School }\end{array}$ & Sengbe & yes & no & 21 & 4 \\
\hline 15 & $\begin{array}{l}\text { Movement of Faith } \\
\text { (MOF) Secondary } \\
\text { School_Koinadugu }\end{array}$ & Sengbe & yes & no & 21 & 4 \\
\hline 16 & $\begin{array}{l}\text { UMC Heritage Secondary } \\
\text { School }\end{array}$ & Sengbe & yes & no & 21 & 4 \\
\hline 17 & $\begin{array}{l}\text { Yiraia Agricultural } \\
\text { Secondary School }\end{array}$ & Sengbe & yes & no & 21 & 5 \\
\hline 18 & Yogomaia Secondary School & Sengbe & yes & no & 21 & 5 \\
\hline 19 & Alkalia Secondary School & Neini & yes & no & 21 & 5 \\
\hline 20 & $\begin{array}{l}\text { Firawa Government } \\
\text { Secondary School }\end{array}$ & Neini & yes & no & 21 & 4 \\
\hline
\end{tabular}




\begin{tabular}{|c|c|c|c|c|c|c|}
\hline$\#$ & Schools & Chiefdom & Jss & sss & ss & TI \\
\hline 21 & $\begin{array}{l}\text { Neini Ballah Memorial } \\
\text { Secondary School }\end{array}$ & Neini & yes & no & 21 & 5 \\
\hline 22 & $\begin{array}{l}\text { Peter Calza Memorial } \\
\text { Agricultural Secondary } \\
\text { School }\end{array}$ & Neini & yes & no & 22 & 4 \\
\hline 23 & $\begin{array}{l}\text { St Anthony Secondary } \\
\text { School }\end{array}$ & Neini & yes & no & 21 & 2 \\
\hline 24 & $\begin{array}{l}\text { Siradu Agricultural Muslim } \\
\text { Seconday School }\end{array}$ & Neini & yes & no & 21 & 5 \\
\hline 25 & $\begin{array}{l}\text { Kurubonla Secondary } \\
\text { School }\end{array}$ & Neya & yes & no & 24 & 5 \\
\hline 26 & $\begin{array}{l}\text { Kasunko Islamic Secondary } \\
\text { School }\end{array}$ & Kasunko & yes & no & 21 & 4 \\
\hline 27 & $\begin{array}{l}\text { Fadugu Agricultural } \\
\text { Secondary School }\end{array}$ & Kasunko & yes & no & 21 & 5 \\
\hline 28 & $\begin{array}{l}\text { Kamukeh Secondary } \\
\text { School }\end{array}$ & Wara Wara Bafodia & yes & no & 21 & 5 \\
\hline 29 & Kabala Secondary School & Wara Wara Yagala & yes & yes & 42 & 8 \\
\hline 30 & $\begin{array}{l}\text { Makakura Secondary } \\
\text { School }\end{array}$ & Sengbe & yes & no & 21 & 5 \\
\hline \multirow[t]{2}{*}{31} & $\begin{array}{l}\text { Bafodia Agricultural } \\
\text { Secondary School }\end{array}$ & Wara Wara Bafodia & yes & yes & 41 & 5 \\
\hline & & TOTAL: & 31 & 5 & 913 & $15^{1}$ \\
\hline
\end{tabular}

